\title{
Effect of bioactivated amaranth grain on the quality and amino acid composition of bread
}

\section{Svitlana Mykolenko, Yana Hez, Oleksandr Pivovarov}

\author{
Dnipro State Agrarian and Economic University, Dnipro, Ukraine
}

Keywords:

Amaranth

Grain

Bread

Amino acid

Article history:

Received 24.02.2021

Received in revised form 19.05.2021

Accepted 30.09.2021

\section{Corresponding}

author:

Svitlana Mykolenko

E-mail:

svetlana.mykolenko@ gmail.com

DOI: $10.24263 / 2304-$ 974X-2021-10-3-11

\section{Abstract}

Introduction. This work is aimed at studying of baking properties and amino acid composition of bioactivated disintegrated amaranth grain as an ingredient for wheat and spelt bread making.

Materials and methods. Amaranth grain of Kharkivskyi-1 variety, soaked at the hydro module of 1:1 for 12-48 hours, was used to obtain bioactivated disintegrated amaranth grain. Consumer, sensory, physicochemical characteristics of wheat and spelt bread, and its protein biological value were analyzed at 15$25 \%$ of the semi-finished product substitution of wheat or spelt flour. Amino acid composition was determined by the ion exchange liquid chromatography.

Results and discussion. Incorporation of the bioactivated disintegrated amaranth grain (BDAG) into wheat and spelt bread formulations at $15-20 \%$ of the flour substitution led to increase in the specific volume of the loaves by $7-21 \%$ due to increased enzymatic activity and improved bioavailability of essential minerals during dough fermentation. The amaranth grain soaking should be 36 hours to achieve the improved sensory properties of the product. The complex quality of the wheat and spelt bread significantly depended on the flour substitution by the BDAG $(56 \%, p=0.007)$ and duration of the amaranth grain soaking $(62 \%$, $\mathrm{p}=0.038)$, respectively. The duration of the amaranth grain soaking had the dominant effect on the quality of the wheat bread and spelt bread with BDAG. Owing to biochemical processes, bioactivated disintegrated amaranth grain showed the improved amino acid score by 1.5-2.7 times for all essential amino acids, and 1.8-2.1 times increased content of essential and nonessential amino acids. Incorporation of $20 \%$ of the BDAG into the wheat bread formulation led to 2.4-fold increase of lysine content in the products, and the scores of essential amino acids reached up 133$213 \%$. Bread with added BDAG contains 1.6-1.7 times more essential and nonessential amino acids. Utility of the protein followed the ascending order: wheat flour $\rightarrow$ amaranth grain $\rightarrow$ wheat bread $\rightarrow$ bioactivated disintegrated amaranth grain $\rightarrow$ wheat bread with bioactivated disintegrated amaranth grain. Protein biological value of the bread with BDAG increased up to $76 \%$.

Conclusions. The duration of the amaranth grain soaking was the dominant factor influencing the bread quality, and providing a significant improvement in the protein biological value. 


\section{- Food Technology -}

\section{Introduction}

Wheat flour and bread made of it have the imperfect amino acid composition, poor in lysine, and contain a small amount of essential macro- and micro-nutrients (Escarnot et al., 2012). Compared to the wheat flour, the flour made of spelt is characterized by the nutritional benefits (Mykolenko et al., 2016), but lower technological properties (Bojnanska, 2002). Bioactivation of grain is a controlled process of grain saturation with moisture and beginning of its sprouting, during which the macromolecular substances are converted into easily digestible ones and biologically active compounds are accumulated (Platel_et al., 2016). In particular, bioactivation leads to the increase in the number of amino acids and improves the product amino acid composition. Bread with partial or complete substitution of flour with bioactivated grain previously disintegrated requires searching for raw materials of high protein biological value (Ruzhylo, 2015) and provides formation of high consumer properties of the product.

Amaranth grain differs from other cereals and legumes by the full value of its amino acid composition (Juan et al., 2007). It is considered that in terms of amino acid composition the amaranth protein the amount of which depending on the genotypic characteristics of the crop and variety varies from 12 to $24 \%$ (Bojórquez-Velázquez et al., 2018) is close to the composition of an ideal protein. Amaranth grain is characterized by high content of lysine, which is the limiting amino acid for vegetable proteins.

It is known that amino acid composition of the product is changing significantly under the influence of the processing technology factors such as temperature, enzymes, and $\mathrm{pH}$ (Martinez-Lopez et al., 2020). The most of studies on the introduction of amaranth grain processing products into bakery goods relate to flour (Mykolenko et al., 2020). Taking into account significant increase in the biological value and bioavailability of grain substances due to sprouting (Platel_et al., 2016), studies of the effect of the bioactivated disintegrated amaranth grain (BDAG) on the quality of bread and changes of its amino acid composition are very promising.

Therefore, purpose of the research was the study of the baking properties and amino acid composition of BDAG as an ingredient of wheat and spelt bread making. The research objectives included the following:

- Determination of the effect of soaking time and BDAG dosing on physico-chemical and sensory properties of wheat and spelt bread;

- Cluster analysis of products by consumer quality indices;

- Study of amino acid composition and protein biological value of grain, flour, bioactivated disintegrated grain and bread with high consumer properties enriched with BDAG.

\section{Materials and methods}

\section{Materials}

The amaranth grain of Kharkivskyi-1 variety of the Ukrainian breeding (Amaranthus hypochondriacus) was used in the study. This variety is positioned by the plant breeders as a medicinal one (Ghopcij et al., 2018). High-grade wheat flour and whole-grain spelt flour were used for the dough preparation. For the wheat flour, the moisture content was $14.5 \%$, amount of gluten $-26 \%$, gluten deformation index (GDI) -63 units; for the spelt bread, the 
moisture content was $11.6 \%$, amount of gluten $-38 \%$, GDI - 88 units. For the baking trial at the laboratory, pressed baker's yeast and table salt were also used.

The amaranth grain cleaned of impurities by optical and vibro-sorting was washed with main water and then soaked at the hydro module of 1:1 (Pivovarov et al., 2018). during 12, 24, 36 and 48 hours. After bioactivation, the grain was disintegrated to form the paste-like disintegrated grain mass, further introduced into the bread formulation in doses, \%: wheat bread - 0 (W), 15 (W15), 20 (W20), 25 (W25); spelt bread - (S), 15 (S15), 20 (S20), 25 (S25). At different durations of soaking of the amaranth grain introduced in the bread as BDAG, hours, the following samples of bread were received: 0 (W and S), 12 (W15-12, W20-12, W25-12; S15-12, S20-12, S25-12); 24 (W15-24, W20-24, W25-24; S15-24, S2024, S25-24); 36 (W15-36, W20-36, W25-36; S15-36, S20-36, S25-36); 48 (W15-48, W2048, W25-48; S15-48, S20-48, S25-48).

\section{Baking trial}

For the dough preparation, we used the composite mixes including wheat flour-BDAG and spelt flour-BDAG in the ratios of 85:15, 80:20, 75:25. The dough was prepared of $200 \mathrm{~g}$ of flour (control sample) or composite mix (test samples), $5 \mathrm{~g}$ of pressed yeast, $3 \mathrm{~g}$ of salt and water as per calculation. The estimated moisture content of the dough for wheat-amaranth mix was equal to $44.5 \%$, and for spelt-amaranth mix $-49 \%$. The dough was fermented in the thermostat at the temperature of $31 \pm 1{ }^{\circ} \mathrm{C}$ for 170 minutes for bread based on wheat flour and at the temperature of $28 \pm 1{ }^{\circ} \mathrm{C}$ for 210 minutes for samples based on spelt flour. The bread was baked in the laboratory oven at the temperature of $220-230{ }^{\circ} \mathrm{C}$ for 30 minutes for wheat bread and $200-210^{\circ} \mathrm{C}$ for 55 minutes for spelt bread.

\section{Determination of physico-chemical characteristics of the bread quality}

Specific volume of the finished products was determined by the method of AACC 1005.01. The complex quality of bread was determined 2-4 hours after baking, taking into account sensory characteristics by scoring on five-point scale with the use of weigh coefficients of the indicators such as volume (3), shape (1), crust color (1), surface condition (1), crumb color (2), crumb porosity structure (1.5), crumb rheological properties (2.5), aroma (2.5), taste (2.5), and chewability of bread crumb (1). Moisture content of the bread crumb was determined by thermographic method according to AACC 44-15.02. Porosity of the finished products was determined using the Zhuravlev device. From the middle of the product a piece of bread of about $7-8 \mathrm{~cm}$ thick was cut. From this piece, the central parts of crumb were taken by the cylinder of the device at a distance of minimum $1 \mathrm{~cm}$ from the crust in the place most typical for its porosity. The cylinder filled with crumb was placed onto the tray so that its rim fitted tightly into the slot of the tray. After that, the column of bread crumb was pushed out of the metal cylinder with a wooden sleeve to the distance of about $1 \mathrm{~cm}$ and cut at the edge of the cylinder with a sharp knife. Then the crumb was pushed out of the cylinder close to the tray wall and cut off again at the edge of the cylinder. Three parts were taken for analysis of the bread. The parts of crumb taken were weighed to the nearest $0.01 \mathrm{~g}$. Porosity $(P, \%)$ was determined by the formula:

$$
P=\frac{V_{t o t}-\frac{G}{\rho}}{V_{t o t}} \times 100, \%
$$

where $V_{\text {tot- }}$ total volume of the parts taken, $\mathrm{cm}^{3}\left(81 \mathrm{~cm}^{3}\right) ; G-$ mass of the parts taken, $\mathrm{g}$; $\rho$-density of nonporous mass of crumb, $\mathrm{g} / \mathrm{cm}^{3}$ (for wheat bread $-1.31 \mathrm{~g} / \mathrm{cm}^{3}$, for spelt bread $\left.-1.21 \mathrm{~g} / \mathrm{cm}^{3}\right)$. 


\section{Determination of amino acid composition and biological value of proteins}

Amino acid composition was determined by the method of ion exchange liquid column chromatography (Csapó et al., 2008) with the use of lithium-citrate buffers as eluents on the automatic amino acid analyzer T 339 ("Microtechna", Czech Republic). For recording of amino acids in the eluents, the method of detection with ninhydrin was used. The experiments were carried out in duplicate. Amino acid score difference factor, biological value and utility of proteins were determined by calculation using the method described in (Dubinina et al., 2015; Shvedjuk et al., 2017).

\section{Statistical processing}

Effect of factors of the amaranth grain soaking time and dosing of BDAG in the bread formulation was determined by two-way analysis of variance (ANOVA). Pearson correlation analysis was carried out at $\mathrm{p}>0.05$, and cluster analysis followed the agglomerative hierarchical clustering procedure (Ward's method).

\section{Results and discussion}

\section{Effect of bioactivated disintegrated amaranth grain on wheat bread and spelt bread quality indicators}

Introduction of non-traditional flour raw materials into the bread formulation has a negative effect on the specific volume (Ayo, 2001; Morita et al., 1999). As can be seen from the Figure 1, addition of BDAG increased the specific volume of test samples compared to the control, except the spelt-amaranth composite mix with the use of disintegrated amaranth grain with soaking time of more than 12 hours. Samples with the duration of amaranth grain soaking of 12-36 hours (Figure 1, a-c) and introduction of disintegrated grain in the bread formulation in the amount of 15-20\% (Figure 1, a-c) corresponded to the best values of the specific volume for the wheat-amaranth mix. For example, compared to the control, specific volume for test samples containing BDAG with the duration of soaking of 12-48 hours increased by $10-21 \%$. When the amaranth grain was soaked for 48 hours, decrease in the specific volume of test samples compared to samples with soaking time of 12-36 hours was recorded. On the other hand, for spelt-amaranth composite mixes the test sample specific volume increased with the use of BDAG soaked for 12 hours (Figure 2, a) by $8-13 \%$ compared to the control after introduction of $15-20 \%$ of BDAG in the spelt bread formulation. The obtained differences between wheat bread and spelt bread with the addition of BDAG are explained by the varying biochemical composition of wheat flour and spelt flour, in particular, the state of their protein-proteinase complex. Spelt flour is characterized by the lower content of insoluble polymeric proteins and higher content of gliadins, which leads to the formation of less elastic gluten of the dough and decrease in its shape-retaining ability (Tilman, 2006). It is known that the amaranth grain introduction reduces the dough elasticity (Silva Grobelnik et al, 2018). Against the background of increased enzymatic activity in spelt dough with BDAG, in particular, with the longer duration of the grain soaking, gas-holding capacity of the dough is decreasing, which results in the products with reduced specific volume compared to the wheat bread. 


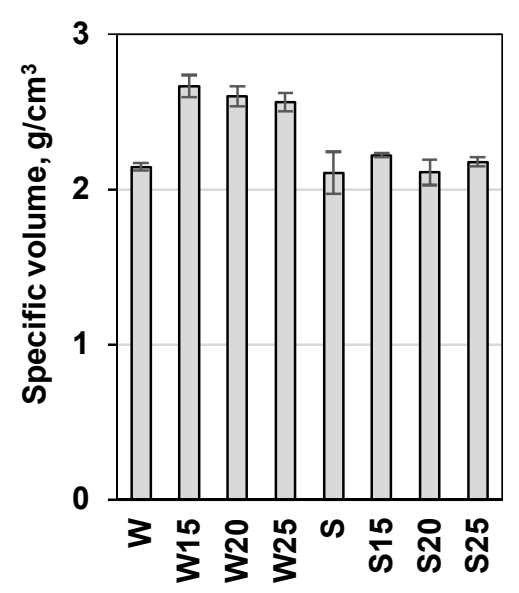

a

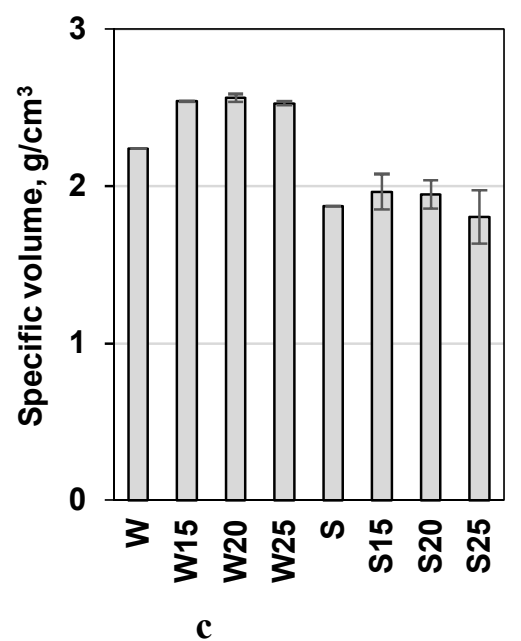

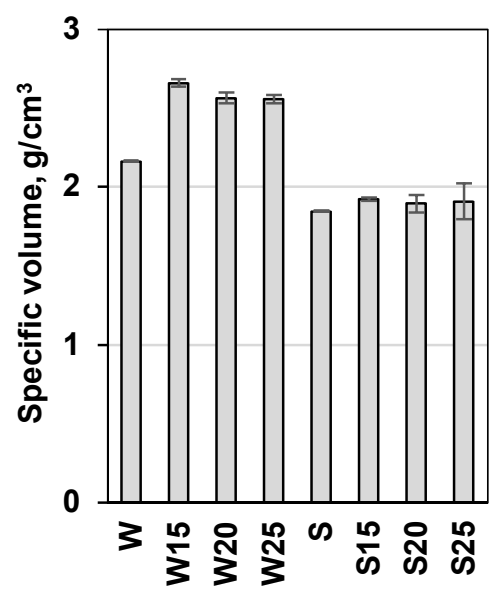

b

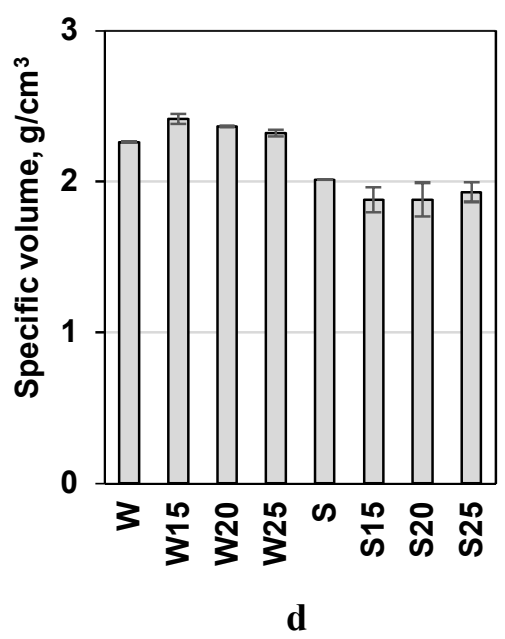

Figure 1. Specific volume of wheat bread (W) and spelt bread (S).

Content of BDAG, \%: W, S - 0; W15, S15 - 15; W20, S20 - 20; W25, S25 - 25.

Duration of the grain soaking (hours): $a-12 ; b-24 ; c-36 ; d-48$

As can be seen from the Figure 2, in terms of complex quality, taking into account sensory characteristics, the best samples were those the formulation of which contained disintegrated amaranth grain soaked for 36 hours for both the wheat bread and spelt bread. It was found that substitution of high-grade wheat flour with BDAG in the amount of $15-25 \%$ had a positive effect on its quality compared to the control sample of the wheat flour, while for the spelt bread it was advisable to substitute max. $15 \%$. Characteristic feature of the wheat bread and spelt bread was the gradual decrease of the finished product quality with the increase in semi-finished product substitution from 20 to $25 \%$ of the flour with BDAG. In all test samples where the amaranth semi-finished product with soaking time of 12 and 24 hours 
was used, a specific taste was observed which had the negative effect on the sensory properties of bread. For the bread with the use of BDAG, soaked for 36-48 hours, no deterioration of taste was recorded. It can be explained by activation of biochemical transformations in the amaranth grain during sprouting, which result in the decrease of concentration of saponins capable of giving a specific taste to the products. For example, reduction of saponins' concentration in the flour of the sprouted amaranth grain compared to the native grain due to sprouting of grain during 48 hours was established by Kumari Beniwal et al, 2019.

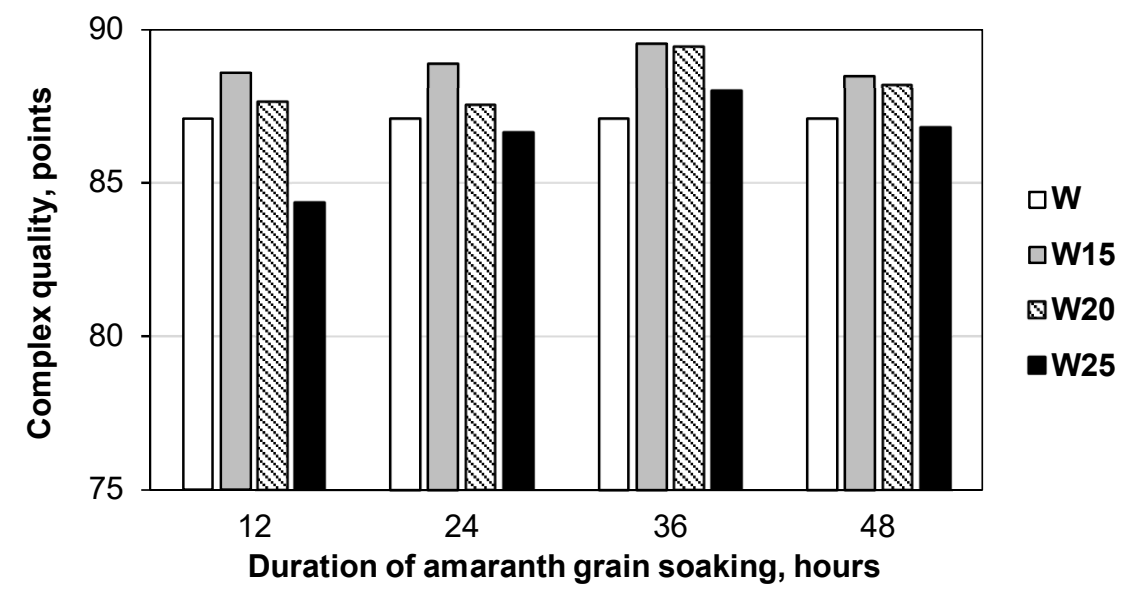

a

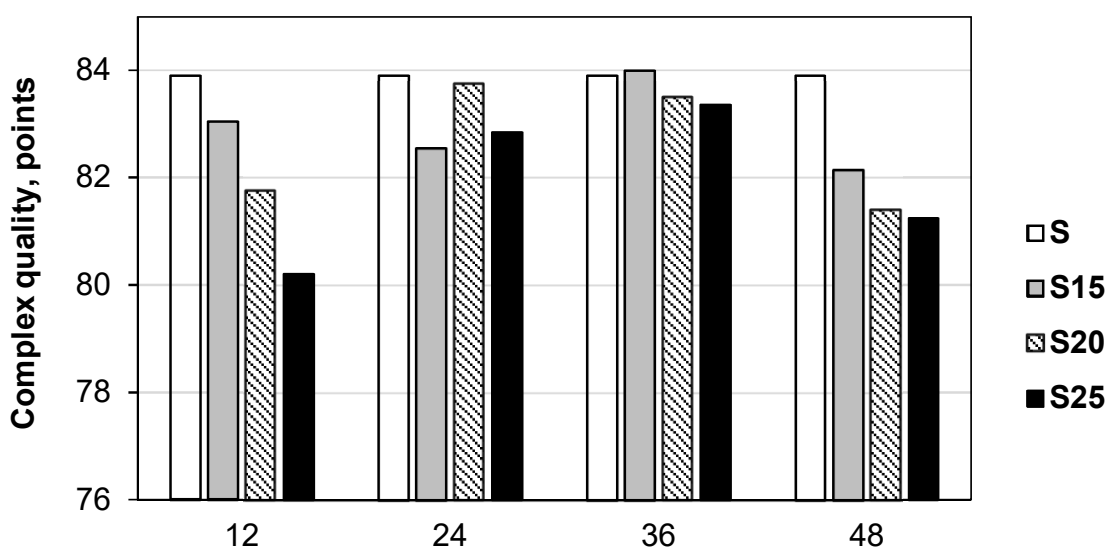

Duration of amaranth grain soaking, hours

b

Figure 2. Complex quality of the wheat bread (a) and spelt bread (b).

BDAG content, \%: W, S - 0; W15, S15 - 15; W20, S20 - 20; W25, S25 - 25. 
The obtained results differ significantly from the data of the authors (Ayo, 2001; Morita et al., 1999), stating the reduction of specific volume and sensory properties of the bread with the use of amaranth flour. Reduction of the bread specific volume in (Ayo, 2001) was apparently due to the dispersion of whole-fat flour, which was less than $0.4 \mathrm{~mm}$ in size, so the maximum allowable percentage of introduced amaranth flour did not exceed $15 \%$. Shmal'ko, 2004, showed the insignificant (1-5\%) growth of the specific volume compared to the obtained results (10-21\%). Moreover, the use of whole-fat amaranth flour of grain of the Kharkivskyi-1 variety increased the complex quality of bread (Mykolenko et al., 2021). This is due to the fact that quality of wheat bread and spelt bread is significantly influenced by the genotypic characteristics of the grain used to obtain BDAG.

Table 1 shows that moisture content of the wheat bread and spelt bread samples under study gradually increased with the growth of BDAG content, which could be related to redistribution of free and bound moisture during soaking of the amaranth grain. Acidity of the wheat bread crumb varied in the range of 1.1-1.4 degrees, while for the spelt bread it was characterized by 2-2.5 times higher acidity. It is due to the presence of peripheral layers of kernel and, accordingly, higher enzymatic activity and acid accumulation in spelt dough during fermentation.

Physico-chemical indicators of quality of the wheat bread and spelt bread with BDAG

\begin{tabular}{|c|c|c|c|c|}
\hline \multicolumn{2}{|r|}{ Sample } & \multirow{2}{*}{$\begin{array}{c}\text { Moisture } \\
\text { content, \% }\end{array}$} & \multirow{2}{*}{$\begin{array}{c}\text { Acidity, } \\
\text { deg. }\end{array}$} & \multirow{2}{*}{$\begin{array}{c}\text { Porosity, } \\
\%\end{array}$} \\
\hline $\begin{array}{c}\text { BDAG } \\
\text { content, } \%\end{array}$ & $\begin{array}{c}\text { Amaranth grain soaking } \\
\text { time, hours }\end{array}$ & & & \\
\hline \multicolumn{2}{|r|}{ Control } & $40.9 \pm 0.14$ & $1.20 \pm 0.14$ & $71.0 \pm 0.71$ \\
\hline \multirow{4}{*}{15} & 12 & $43.3 \pm 0.14$ & $1.20 \pm 0.01$ & $71.0 \pm 0.58$ \\
\hline & 24 & $43.0 \pm 0.01$ & $1.20 \pm 0.01$ & $71.0 \pm 0.37$ \\
\hline & 36 & $43.3 \pm 0.14$ & $1.40 \pm 0.01$ & $75.1 \pm 0.45$ \\
\hline & 48 & $43.5 \pm 0.14$ & $1.20 \pm 0.01$ & $78.0 \pm 0.01$ \\
\hline \multirow{4}{*}{20} & 12 & $43.4 \pm 0.01$ & $1.10 \pm 0.14$ & $70.1 \pm 0.01$ \\
\hline & 24 & $44.3 \pm 0.14$ & $1.10 \pm 0.14$ & $71.0 \pm 1.17$ \\
\hline & 36 & $43.9 \pm 0.14$ & $1.40 \pm 0.01$ & $74.0 \pm 0.47$ \\
\hline & 48 & $44.4 \pm 0.00$ & $1.20 \pm 0,01$ & $77.1 \pm 0.01$ \\
\hline \multirow{4}{*}{25} & 12 & $44.1 \pm 0.14$ & $1.20 \pm 0,01$ & $73.1 \pm 0.18$ \\
\hline & 24 & $44.0 \pm 0.01$ & $1.20 \pm 0,01$ & $74.0 \pm 0.56$ \\
\hline & 36 & $44.6 \pm 0.01$ & $1.40 \pm 0.01$ & $77.0 \pm 0,71$ \\
\hline & 48 & $44.6 \pm 0.01$ & $1.40 \pm 0.01$ & $77.1 \pm 0.01$ \\
\hline \multicolumn{2}{|r|}{ Control } & $47.2 \pm 0.14$ & $3.50 \pm 0.14$ & $64.0 \pm 0.71$ \\
\hline \multirow{4}{*}{15} & 12 & $47.2 \pm 0.01$ & $3.10 \pm 0.14$ & $60,1 \pm 0.01$ \\
\hline & 24 & $48.8 \pm 0.01$ & $3.10 \pm 0.01$ & $61.1 \pm 2.12$ \\
\hline & 36 & $48.1 \pm 0.14$ & $3.20 \pm 0.01$ & $70.1 \pm 0.34$ \\
\hline & 48 & $48.5 \pm 0.14$ & $3.10 \pm 0.14$ & $71.0 \pm 1.41$ \\
\hline \multirow{4}{*}{20} & 12 & $48.1 \pm 0.14$ & $2.90 \pm 0.14$ & $62.1 \pm 1.41$ \\
\hline & 24 & $49.1 \pm 0.14$ & $2.90 \pm 0.14$ & $62.1 \pm 0.01$ \\
\hline & 36 & $49.1 \pm 0.01$ & $3.20 \pm 0.01$ & $63.0 \pm 2.12$ \\
\hline & 48 & $48.6 \pm 0.01$ & $3.10 \pm 0.14$ & $73.1 \pm 0.71$ \\
\hline \multirow{4}{*}{25} & 12 & $48.7 \pm 0.14$ & $2.80 \pm 0.01$ & $62.0 \pm 2.12$ \\
\hline & 24 & $49.1 \pm 0.14$ & $2.80 \pm 0.01$ & $64.1 \pm 0.71$ \\
\hline & 36 & $48.7 \pm 0.14$ & $3.20 \pm 0.01$ & $62.0 \pm 0.71$ \\
\hline & 48 & $49.6 \pm 0.01$ & $3.00 \pm 0.01$ & $66.0 \pm 0.71$ \\
\hline
\end{tabular}


There was the increase in the porosity of wheat bread and spelt bread for the test samples compared to the control upon the introduction of semi-finished product, soaked for 36-48 hours, by 1.1 and 1.2 times, respectively. It is consistent with the results of studies (Shmal'ko, 2004), establishing the increase in crumb porosity by $7-9 \%$ with 10 and $20 \%$ substitution of wheat flour with disintegrated amaranth grain. The resulting effect can be explained by the increase in sugars content available for fermentation by yeast. For example, Guardianelli et al., 2021, has found that due to sprouting of the amaranth grain the content of fructose and glucose increased 10 and 5 times, respectively, capable of intensifying gas formation in the dough.

\section{Statistical analysis of results of study of the effect of bioactivated amaranth grain on the quality of wheat bread and spelt bread}

Two-factor analysis of variance (Table 2) showed that BDAG dosing and duration of grain soaking had no effect at the significance level of $p>0.05$ on the specific volume of both wheat bread and spelt bread. The effect of the factor of BDAG dosing (56\%) on the complex quality of the wheat bread with BDAG $(p=0,007)$ has been established. On the contrary, complex quality of spelt bread was influenced by the duration of soaking of amaranth $(62 \%)$ at $\mathrm{p}=0,038$. Moisture content of the crumb depended on the factor of BDAG dosing at the level of $69 \%(\mathrm{p}=0.007)$ and $37 \%(\mathrm{p}=0,038)$ for the wheat bread and spelt bread, respectively.

Table 2

Effect of factors of amaranth grain soaking time (T) and dosing of bioactivated disintegrated amaranth grain (D) on the bread quality

\begin{tabular}{|c|c|c|c|c|c|c|c|c|}
\hline \multirow{2}{*}{$\begin{array}{c}\text { Type of bread with } \\
\text { BDAG }\end{array}$} & \multicolumn{2}{|c|}{ Complex quality } & \multicolumn{2}{|c|}{ Moisture content } & \multicolumn{2}{|c|}{ Acidity } & \multicolumn{2}{|c|}{ Porosity } \\
\hline & $\mathbf{T}$ & D & $\mathbf{T}$ & D & $\mathbf{T}$ & D & $\mathbf{T}$ & D \\
\hline Wheat bread & ++ & - & - & ++ & +++ & - & +++ & + \\
\hline Spelt bread & - & ++ & - & + & ++ & - & - & - \\
\hline
\end{tabular}

Note: $(-)-$ no effect of the factor; $(+)-10-50 \%$ effect of the factor; $(++)-50-70 \%$ effect of the factor; $(+++)-70-90 \%$ effect of the factor.

Acidity of the crumb was affected by the factor of the grain soaking duration and the level of its influence was higher: $73 \%(p=0.007)$ i $60 \%(p=0.018)$ for the wheat bread and spelt bread, respectively. Obviously, it is due to the activation of biochemical processes during grain soaking and accumulation in the amaranth grain of hydrolytic enzymes actively involved in acid accumulation in the process of preparation of the dough. In particular, increase of total and amine nitrogen by 1.3-1.4 times, proteolytic enzyme activity increase by 1.4-1.5 times, and that of lipase and lipoxygenase by 1.1-1.2 times was established in another study (Shmal'ko, 2004). Two factors simultaneously featured statistically significant effect on the porosity of the wheat bread at the level of $82 \%(p=0.0008)$ and $12 \%(p=0.04)$ for the duration of amaranth grain soaking and BDAG dosing, respectively.

The correlation analysis showed statistically significant positive Pearson correlation for the specific volume on the porosity of wheat bread with BDAG $(0.67)$ and its acidity $(0.62)$. For the spelt bread with BDAG, in its turn, the positive correlation (0.62) of the complex quality of bread and its acidity was statistically significant. 
Formation of different clusters for the wheat bread and spelt bread with BDAG (Figure 3 ) was established. At the affinity level 2 for the wheat bread two clusters were formed: the first cluster included the indicators of specific volume, porosity, acidity and moisture content, and the second one - complex quality as the indicator for samples characterized by the lowest statistical affinity.

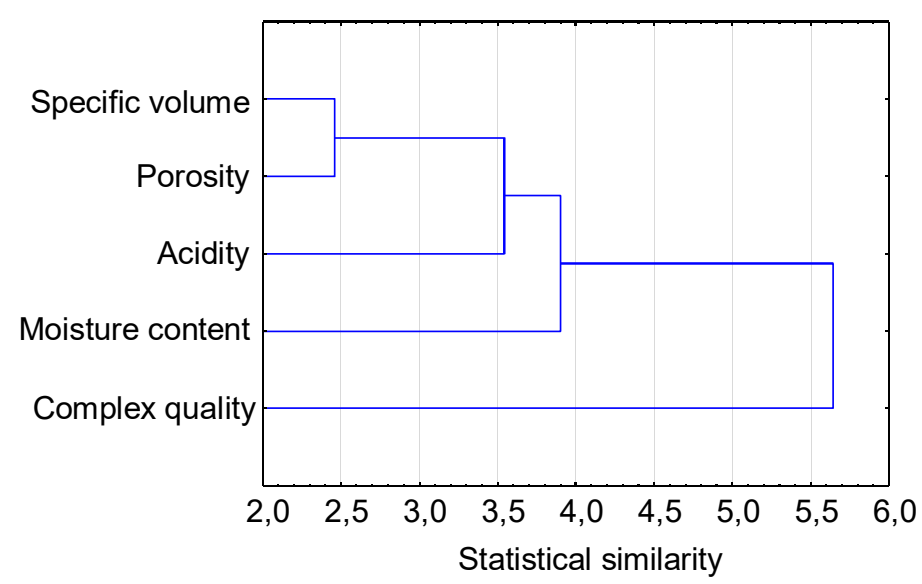

$\mathbf{a}$

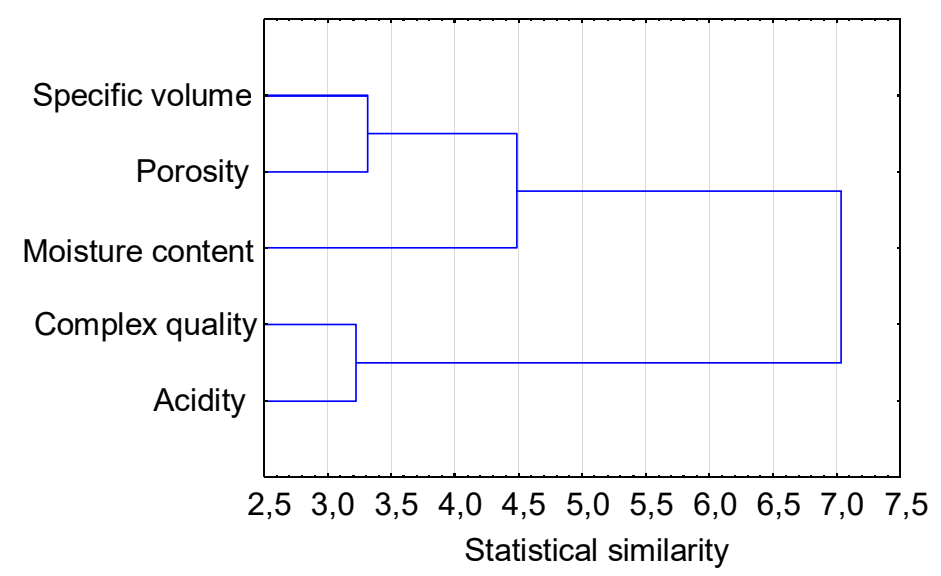

b

Figure 3. Cluster analysis of wheat bread (a) and spelt bread (b) by quality indicators 
It should be noted that specific volume and porosity showed the highest statistical affinity in samples, as well as positive correlation between themselves. This subcluster formed a separate group with acidity, but statistically significant correlation was found only for the indicator of specific volume and acidity. For samples of spelt bread with BDAG at the same level of affinity 3 clusters were formed: the first cluster included the specific volume and porosity, the second one - moisture content, and the third was formed by the complex quality and acidity of the crumb (Figure 3, b). According to the results of the correlation analysis, the last cluster also showed statistically significant positive correlation between the indicators for spelt bread in contrast to wheat bread. It indicates a significant contribution of organic acids and acid-reactive compounds in the quality of spelt bread with BDAG, which was characterized by more pronounced aroma and taste compared to wheat bread with BDAG.

Cluster analysis of dendrograms of samples evaluated by the bread quality indicators (Figure 4) showed that at the level of statistical similarity 6, four separate clusters were formed.

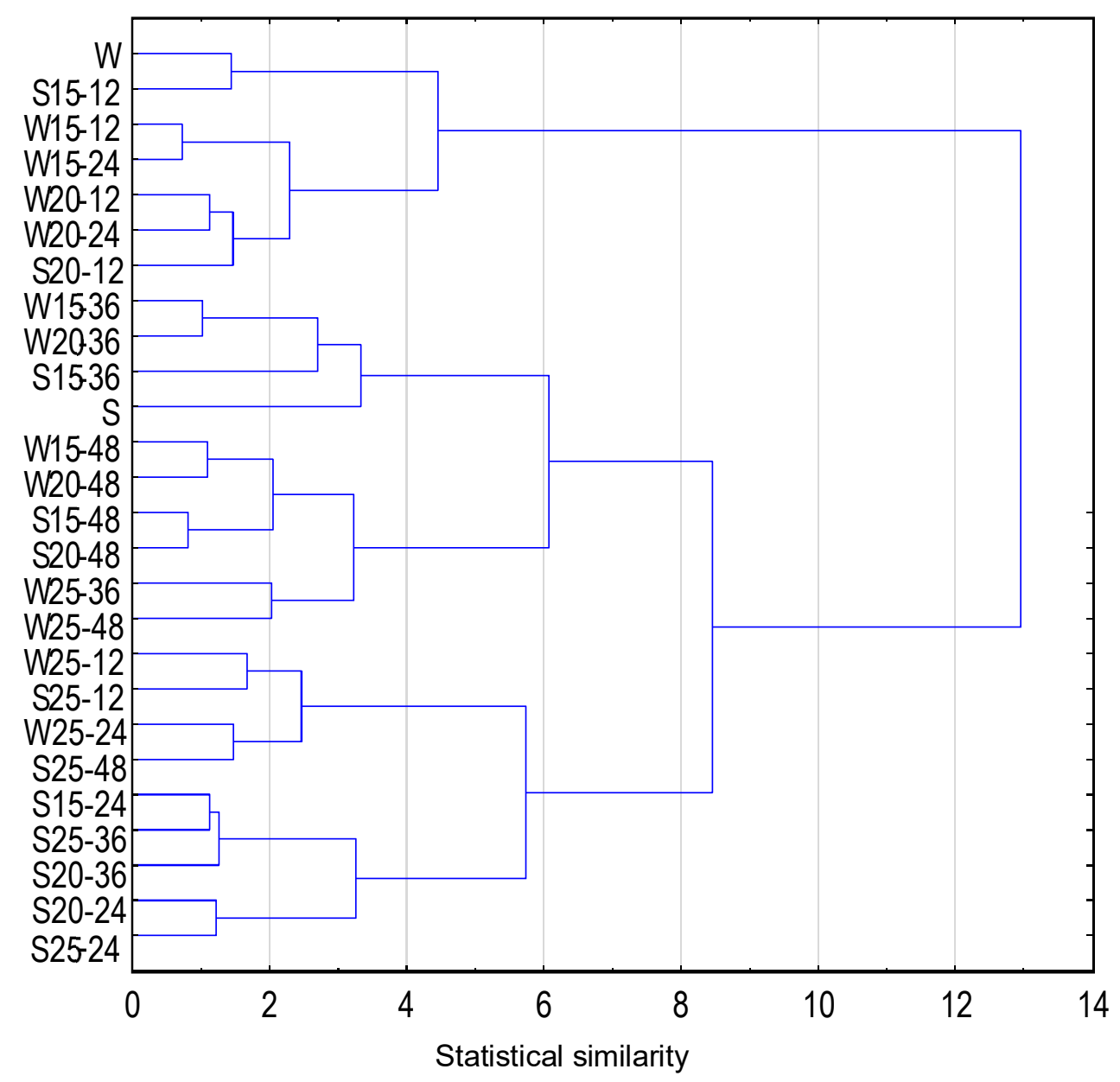

Figure 4. Cluster analysis of test samples of bread 
The first one included a control sample of wheat bread and test samples of wheat bread (5) and spelt bread (2) with $15-20 \%$ of BDAG, soaked for 12-24 hours. It means that low levels of factors of the duration of amaranth grain soaking and BDAG dosing had no significant effect on the quality of bread. The second cluster included a control sample of spelt bread and test samples of wheat bread (2) and spelt bread (1) with 15-20\% of BDAG, soaked for 36 hours. The third cluster combined the samples of wheat bread (4) and spelt bread (1) made on condition of 48 hours of amaranth grain soaking and all levels of BDAG introduction. The fourth cluster consisted mainly of spelt bread samples (8) and only 2 samples of wheat bread with BDAG. The latter clusters had the highest BDAG concentration and minimum 12-24 hour soaking time of the amaranth grain.

Cluster showed that the highest similarity was typical for the following bread samples in descending order: W15-12-W15-24 $\rightarrow$ S15-48-S20-48 $\rightarrow$ W15-36-W20-36 $\rightarrow$ W15$48-W 20-48 \rightarrow$ S15-24-S25-36-S20-36 $\rightarrow$ S20-24-W25-24. Along with the results of two-way analysis of variance, it indicates the dominant effect of the duration of amaranth grain soaking in the production of both wheat bread and spelt bread with BDAG.

\section{Assessment of biological value of protein}

Tables 3, 4, and Figure 5 show the results of studies of the amino acid composition of amaranth grain before and after biological activation and disintegration compared to highgrade wheat flour, as well as wheat bread and bread made with the addition of $20 \%$ of BDAG, featuring the highest consumer properties.

The amaranth grain differed significantly in amino acid composition from the wheat flour, despite the presence of the same limiting acids of the protein (isoleucine and valine), scores on which were slightly higher for the amaranth grain. In contrast to the wheat flour, valine, isoleucine, and leucine only had amino acid scores below 50\%. Lysine was the dominant amino acid of the amaranth grain (with 85\% amino acid score), whereas for the wheat flour its value reached up 39\%. Besides, as a result of biochemical processes occurring in the amaranth grain during soaking, in particular, 1.2-1.5 times increase in the activity of proteolytic enzymes (Shmal'ko, 2004), disintegrated amaranth grain was characterized by the improved amino acid score for all essential amino acids by 1.5-2.7 times. BDAG protein featured the highest score for lysine, phenylalanine and tyrosine (137 and 165 respectively), thus bringing the protein of such raw materials closer to the composition of animal proteins.

Amino acid composition of bread was characterized by growing scores of all essential amino acids, but for the wheat bread lysine still remained the limiting amino acid $(62 \%)$ in contrast to the wheat bread made with the addition of $20 \%$ of BDAG, where lysine content was 2.4 times higher compared to the control sample of bread. For the wheat bread, isoleucine remained the second limiting acid, which was not present in the wheat flour, while for test samples of bread enriched with disintegrated amaranth grain, valine and isoleucine were limiting ones. All essential amino acids of the bread under study had the scores of $133-213 \%$, which proved a significant improvement in the amino acid composition of the product protein when using BDAG. All analyzed nonessential and conditionally essential amino acids of test samples of bread in their number exceeded the wheat bread (Figure 5): bread with the addition of BDAG contained 1.7 and 1.6 times more essential and nonessential amino acids. The process of bioactivation (grain soaking) also had a positive impact on the raw materials: the number of essential and nonessential amino acids in the amaranth grain doubled after bioactivation and disintegration. 
Table 3

Amino acid content in raw materials, bioactivated disintegrated amaranth grain and bread with BDAG

\begin{tabular}{|c|c|c|c|c|c|c|c|c|c|c|c|}
\hline \multirow[b]{2}{*}{ 导 冚 } & \multirow{2}{*}{ 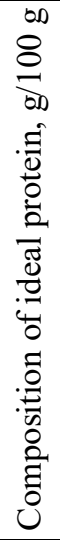 } & \multicolumn{2}{|c|}{$\begin{array}{l}\text { Wheat } \\
\text { flour }\end{array}$} & \multicolumn{2}{|c|}{$\begin{array}{c}\text { Native } \\
\text { amaranth } \\
\text { grain }\end{array}$} & \multicolumn{2}{|c|}{$\begin{array}{l}\text { BDAG, } \\
\text { soaking } 36 \\
\text { hours }\end{array}$} & \multicolumn{2}{|c|}{$\begin{array}{l}\text { Wheat } \\
\text { bread }\end{array}$} & \multicolumn{2}{|c|}{$\begin{array}{c}\text { Bread with } \\
20 \% \\
\text { BDAG, } \\
\text { soaking } 36 \\
\text { hours }\end{array}$} \\
\hline & & 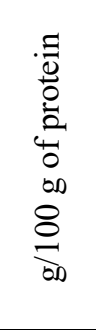 & 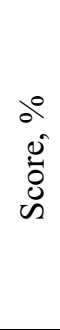 & 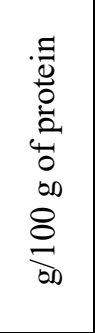 & 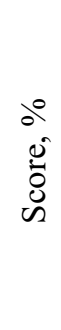 & 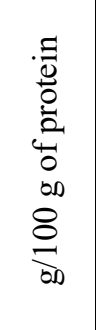 & $\begin{array}{l}00 \\
0 \\
0 \\
0 \\
\tilde{n}\end{array}$ & 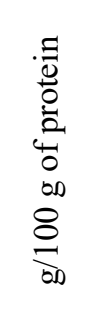 & $\begin{array}{l}00 \\
0 \\
0 \\
0 \\
\tilde{n}\end{array}$ & $\begin{array}{l}\cdot \Xi \\
0 \\
0 \\
0 \\
0 \\
40 \\
0 \\
0 \infty \\
8 \\
8 \\
0 \\
0\end{array}$ & $\begin{array}{l}0^{\circ} \\
0 \\
0 \\
0 \\
\tilde{U}\end{array}$ \\
\hline Lysine & 5.5 & 2.12 & 39 & 4.65 & 85 & 7.54 & 137 & 3.39 & 62 & 8.22 & 149 \\
\hline Histidine & - & 1.07 & - & 1.64 & - & 3.51 & - & 2.43 & - & 3.79 & - \\
\hline Arginine & - & 2.54 & - & 5.05 & - & 11.30 & - & 2.87 & - & 6.81 & - \\
\hline Asparagine acid & - & 2.25 & - & 4.71 & - & 9.49 & - & 5.21 & - & 9.22 & - \\
\hline Threonine & 4 & 1.47 & 37 & 2.36 & 59 & 5.18 & 130 & 3.44 & 86 & 5.41 & 135 \\
\hline Serine & - & 3.02 & - & 4.31 & - & 7.31 & - & 5.30 & - & 8.57 & - \\
\hline Glutamic acid & - & 23.05 & - & 12.93 & - & 18.90 & - & 30.70 & - & 46.4 & - \\
\hline Proline & - & 7.64 & - & 2.43 & - & 1.04 & - & 11.78 & - & 19.7 & - \\
\hline Glycine & - & 2.54 & - & 4.35 & - & 8.99 & - & 3.88 & - & 7.36 & - \\
\hline Alanine & - & 2.11 & - & 3.40 & - & 4.48 & - & 3.23 & - & 5.73 & - \\
\hline Valine & 5 & 1.68 & 34 & 1.95 & 39 & 4.58 & 92 & 4.28 & 86 & 6.81 & 136 \\
\hline $\begin{array}{l}\text { Methionine+ } \\
\text { Cystine }\end{array}$ & 3.5 & 1.66 & 47 & 2.24 & 64 & 3.39 & 97 & 3.37 & 96 & 6.08 & 174 \\
\hline Isoleucine & 4 & 1.20 & 30 & 1.49 & 37 & 3.90 & 98 & 3.24 & 81 & 5.32 & 133 \\
\hline Leucine & 7 & 4.14 & 59 & 3.18 & 45 & 6.97 & 100 & 7.30 & 104 & 11.25 & 161 \\
\hline $\begin{array}{l}\text { Phenylalanine } \\
+ \text { tyrosine }\end{array}$ & 6 & 4.42 & 74 & 4.59 & 76 & 9.90 & 165 & 8.15 & 136 & 12.8 & 213 \\
\hline
\end{tabular}

Table 4

Biological value of raw protein, bioactivated disintegrated amaranth grain and bread with BDAG

\begin{tabular}{|l|c|c|c|c|c|}
\hline Indicator of protein value & $\begin{array}{c}\text { Wheat } \\
\text { flour }\end{array}$ & $\begin{array}{c}\text { Native } \\
\text { amaranth } \\
\text { grain }\end{array}$ & $\begin{array}{c}\text { BDAG, } \\
\text { soaking } \\
36 \text { hours }\end{array}$ & $\begin{array}{c}\text { Wheat } \\
\text { bread }\end{array}$ & $\begin{array}{c}\text { Bread with } \\
\text { 20\% BDAG, } \\
\text { soaking 36 } \\
\text { hours }\end{array}$ \\
\hline AASDF, \% & 15.5 & 20.6 & 25.1 & 31.3 & 24.2 \\
\hline BV, \% & 84.5 & 79.4 & 74.9 & 68.7 & 75.8 \\
\hline Utility of the protein & 0.63 & 0.64 & 0.77 & 0.65 & 0.83 \\
\hline
\end{tabular}




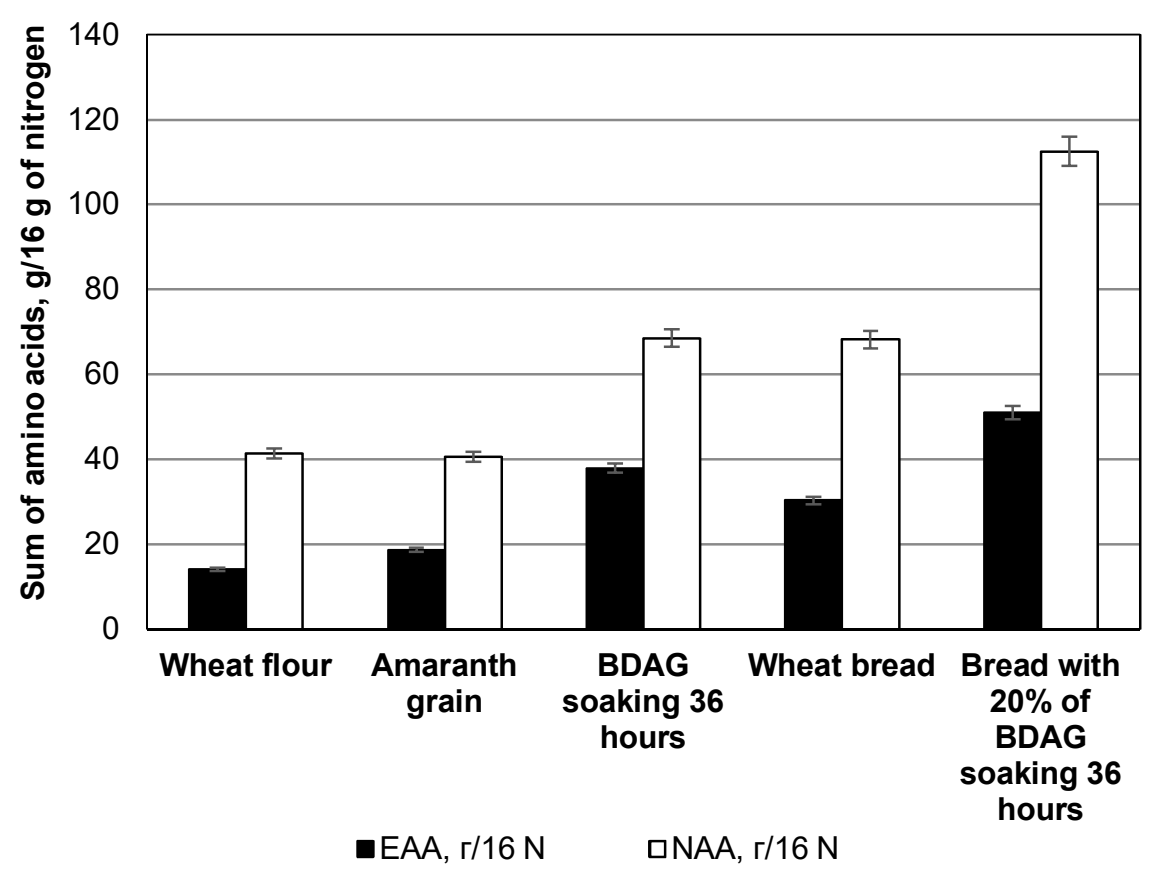

Figure 5. Content of essential and nonessential amino acids in raw materials and bread of bioactivated disintegrated amaranth grain

Amino acid score difference factor was lower for the bread with BDAG, so the protein biological value of such bread increased up to $76 \%$, whereas for the control sample this value was equal to $69 \%$. It should be noted that utility of protein, as its ability to be absorbed by the body for plastic needs, was arranged in ascending order: high-grade wheat flour $\rightarrow$ amaranth grain without treatment $\rightarrow$ wheat bread $\rightarrow$ bioactivated disintegrated amaranth grain $\rightarrow$ bread with bioactivated disintegrated amaranth grain. Increase in the grain protein biological value as a result of enzymatic processes agrees with (Szabóová et al., 2020; Búcaro Segura et al., 2002), where the improvement of amino acid composition of the protein and increase in the level of its digestibility were established.

\section{Conclusions}

1. Usage of BDAG in the formulation of the wheat bread and spelt bread increased the specific volume of products by $10-21 \%$ and $8-13 \%$, when the amaranth semi-finished product was introduced in the amount of max. $20 \%$. For the wheat-amaranth mix, according to the sensory assessment, it was expedient to substitute high-grade wheat flour with BDAG in the amount of $15-20 \%$, and for spelt-amaranth mix this amount was max. $15 \%$ at soaking time of 36 hours. Spelt bread with BDAG compared to wheat bread was characterized by $2.4-3$ times increase in the crumb acidity and 1.1-1.2 times 
reduction of porosity. Complex quality of the wheat bread and spelt bread significantly depended on the flour substitution by the bioactivated disintegrated amaranth grain $(56 \%, \mathrm{p}=0.007)$ and duration of the amaranth grain soaking $(62.3 \%, \mathrm{p}=0.038)$, respectively. Acidity of the crumb was affected by the factor of the duration of the grain soaking at the level of $73 \%, \mathrm{p}=0.007$, and $60 \%, \mathrm{p}=0.018$, for the wheat bread and spelt bread, respectively. It was found that porosity of bread at the statistically significant level depends more on the duration of the amaranth grain soaking $(82 \%, \mathrm{p}=0.0008)$ than on the amount of BDAG introduced into the formulation $(12 \%, \mathrm{p}=0.04)$. Positive correlation between the specific volume of wheat bread and its porosity (0.67) and acidity ( 0.62$)$ was found. For spelt bread with BDAG, positive correlation between the complex quality of bread (0.62) and its acidity was statistically significant.

2. According to the results of cluster analysis of dendrograms of samples assessed by the indicators of bread quality, it was found that low levels of factors of duration of amaranth grain soaking (12-24 hours) and BDAG dosing (15-20\%) had no significant effect on the quality of bread. The highest statistical similarity was typical for the following bread samples in descending order: W15-12-W15-24 $\rightarrow$ S15-48-S20-48 $\rightarrow \mathrm{W} 15-36-\mathrm{W} 20-36 \rightarrow \mathrm{W} 15-48-\mathrm{W} 20-48 \rightarrow \mathrm{S} 15-24-\mathrm{S} 25-36-\mathrm{S} 20-36 \rightarrow \mathrm{S} 20-24-$ W25-24. Along with the results of two-way analysis of variance, it indicated the dominant effect of the duration of amaranth grain soaking in the production of both wheat and spelt bread with the use of BDAG.

3. For the amaranth grain, valine, isoleucine and leucine had amino acid scores below $50 \%$, whereas for wheat flour - lysine, threonine, valine, methionine, cystine and isoleucine. In terms of lysine content, the amaranth grain exceeded the wheat flour twofold. As a result of biochemical processes occurring in the kernel during soaking, disintegrated amaranth grain was characterized by the improved amino acid score for all essential amino acids by 1.5-2.7 times. BDAG protein featured the highest scores for lysine, phenylalanine and tyrosine (137 and 165 respectively), thus bringing the protein of such raw materials closer to the composition of animal proteins. For the wheat bread made with the addition of $20 \%$ of BDAG, lysine content was 2.4 times higher compared to the control sample of bread. All essential amino acids of the bread under study had scores of $133-213 \%$, which proved the significant improvement of amino acid composition of protein in the product with the use of BDAG. As a result of bioactivation, the amaranth grain had 1.8-2.1 times higher content of essential and nonessential amino acids, the amount of which in the bread with BDAG increased by $1.6-1.7$ times.

4. Protein biological value for the bread with BDAG increased up to $76 \%$, whereas for the control sample this value was equal to $69 \%$. Utility of the protein followed the ascending order: high-grade wheat flour $\rightarrow$ amaranth grain without treatment $\rightarrow$ wheat bread $\rightarrow$ bioactivated disintegrated amaranth grain $\rightarrow$ bread with bioactivated disintegrated amaranth grain.

Acknowledgement. This work is based upon the work from COST Action 18101 SOURDOMICS-Sourdough biotechnology network towards novel, healthier and sustainable food and bioprocesses (https://sourdomics.com/;https://www.cost.eu/actions/CA18101/), where the author S.M. is MC Observer from Ukraine. COST is a funding agency for research and innovation networks. Also, this work was supported by the Ukrainian State Project for Young Scientists of the Ministry of Education and Science of Ukraine (No. 0120U100322). The authors are also grateful to Olexandr Duda, President of the Association of Amaranth and Amaranth Products, for providing the amaranth grain. 


\section{References}

Ayo J.A. (2001), The effect of amaranth grain flour on the quality of bread, International journal of food properties, 4(2), pp. 341-351.

Bojnanska T. (2002), The use of spelt wheat (Triticum spelta L.) for baking applications, Rostlinna Vyroba, 48, pp. 141-147.

Bojórquez-Velázquez E., Velarde-Salcedo A.J., De León-Rodríguez A., Jimenez-Islas H., Pérez-Torres J.L., Herrera-Estrella A., Espitia-Rangel E., de la Rosa A.P.B. (2018), Morphological, proximal composition, and bioactive compounds characterization of wild and cultivated amaranth (Amaranthus spp.) species, Journal of Cereal Science, 83, pp. 222-228.

Búcaro Segura M.E., Bressani R. (2002), Protein fraction distribution in milling and screened physical fractions of grain amaranth, Archivos Latinoamericanos de Nutrición, 52(2), pp. $167-171$.

Csapó J., Albert C., Lóki K., Csapó-Kiss Z. (2008), Separation and determination of the amino acids by ion exchange column chromatography applying postcolumn derivatization, Acta Universitatis Sapientiae, 1, pp. 5-29.

Dubinina A.A., Lenert S.O., Popova T.M. (2015), Analiz aminokyslotnogho skladu ta biologhichnoji cinnosti bilka krupy iz ghrechky riznykh sortiv, Tekhnologhycheskyj audyt y rezervbl proyzvodstva, 4(4). pp. 55-61.

Escarnot E., Jacquemin J-M, Agneessens R., Paquot M. (2012), Comparative study of the content and profiles of macronutrients in spelt and wheat, a review, Biotechnology, Agronomy, Society and Environment, 16(2), pp. 243-256.

Ghopcij T.I., Voronkov M.F., Bobro M.A., Miroshnychenko L.O., Lymansjka S.V., Ghudym O.V., Ghudkovsjka N.B., Duda Ju.V. (2018), Amarant: selekcija, ghenetyka ta perspektyvy vyroshhuvannja, KhDUKhT, Kharkiv.

Guardianelli L.M., Salinas M.V., Puppo M.C. (2021), Quality of wheat breads enriched with flour from germinated amaranth seeds, Food Science and Technology International, $0(0)$, pp. 1-9.

Juan R, Pastor J, Alaiz M, Megías C, Vioque J. (2007), Seed protein characterisation of eleven species of amaranthus, Grasas y Aceites, 58(1), pp. 49-55.

Kumari Beniwal S., Devi A., Sindhu R. (2019). Effect of grain processing on nutritional and physico-chemical, functional and pasting properties of amaranth and quinoa flours, Indian Journal of Traditional Knowledge, 18(3), pp. 500-507.

Martinez-Lopez A.M., Millan-Linares M.C., Rodriguez-Martin N.M., Millan F., Montserratde la Paza S. (2020), Nutraceutical value of kiwicha (Amaranthus caudatus L.), Journal of Functional Foods, 65, pp. 1-13.

Morita N, Kang W., Hamauzu Z., Sugimoto Y. (1999), Effect of amaranth flour on some properties of wheat dough and bread, Journal of Applied Glycoscience, 46(1), pp. 2330 .

Mykolenko S.Ju., Ghezj Ja.V. (2016), Doslidzhennja khlibopekarsjkykh vlastyvostej speljtovogho ta gharbuzovogho boroshna pry vykorystanni plazmokhimichno aktyvovanoji vody, Prodovoljchi resursy. Zbirnyk naukovykh pracj, 7, pp. 170-177.

Mykolenko S., Zhygunov D., Rudenko T. (2021), Baking properties of different amaranth flours as wheat bread ingredients, Food Science and Technology, 14(4), pp. 62-71.

Mykolenko S.Yu., Zakharenko A.V. (2020), Doslidzhennia vplyvu amarantovoho ta Inianoho boroshna na yakist pechyva, Tekhnichni nauky ta tekhnolohii, 1(19), pp. $228-240$. 
Pivovarov A., Mykolenko S., Hez, Y., Shcherbakov S. (2018), Plasma-chemically activated water influence on staling and safety of sprouted bread, Journal of Food Science and Technology-Ukraine, 12(2), pp. 100-107.

Platel K., Krishnapura Srinivasan K. (2016), Bioavailability of Micronutrients from Plant Foods: An Update, Food Science and Nutrition, 56(10), pp. 1608-1619.

Ruzhilo N.S. (2015), Ispol'zovanie semjan amaranta v hlebobulochnyh izdelijah, Pishhevaja promyshlennost', 12, pp. 56-58.

Shmal'ko N.A. (2004), Ispol'zovanie dispergirovannyh semjan amaranta v hlebopechenii, Hlebopek, 1, pp. 24-26.

Shvedjuk D.A., Pasichnyj V.M., Radzijevsjka I.Gh., Macuk Ju A. (2017), Aminokyslotnyj sklad ta biologhichna cinnistj m'jasnykh napivfabrykativ z vykorystannjam roslynnoji syrovyny ta bilkovo-zhyrovykh emuljsij, Naukovyj visnyk Ljvivsjkogho nacionaljnogho universytetu veterynarnoji medycyny ta biotekhnologhij imeni S.Z. Gzhycjkogho. Serija: Kharchovi tekhnologhiji, 19(80), pp. 111-114.

Silva Grobelnik M, Bavec M., Turinek M., Bavec F. (2018), Rheological properties of dough made from grain amaranth-cereal composite flours based on wheat and spelt, Czech Journal of Food Sciences, 27, pp. 309-319.

Szabóová M., Záhorský M., Gažo J.,Geuens J., Vermoesen A., D'Hondt E., Hricová A. (2020), Differences in seed weight, amino acid, fatty acid, oil, and squalene content in $\gamma$-irradiation-developed and commercial amaranth varieties (Amaranthus spp.), Plants, 9(11), pp. 1-15.

Tilman S., Scott R.B., Manfred K. (2006), Gluten proteins from spelt (Triticum aestivum ssp. spelta) cultivars: A rheological and size-exclusion high-performance liquid chromatography study, Journal of Cereal Science, 44(2), pp. 161-173. 


\title{
Effects of the sugar and fat substitution on the rheological properties of the pie dough
}

\author{
Dana Huțu, Sonia Amariei
}

Stefan cel Mare University of Suceava, Suceava, Romania

\begin{tabular}{l}
\hline Keywords: \\
Pie \\
Dough \\
Rheology \\
Sugar \\
Fat \\
Apple puree \\
\end{tabular}

Article history:

Received 30.04.2021

Received in revised

form 08.09.2021

Accepted 30.09.2021

\section{Corresponding \\ author:}

Dana Huțu

E-mail:

dana.hutu@outlook.com

DOI: $10.24263 / 2304-$

974X-2021-10-3-12

\section{Abstract}

Introduction. The aim of this research was to determine the impact on the rheological properties of the pie dough in the case of substitution of a percentage of sugar and fat with apple puree.

Materials and methods. The evaluation of the empirical rheological characteristics of the pie dough was performed using the Alveograph tool. For the evolution of the loss and storage behaviour of the dough during processing were performed two dynamic methods: frequency and creep test.

Results and discussion. The rheological properties of the doughs showed significant changes in the case of samples obtained by substituting a lower percentage of sugar and fat with apple puree. Lower values of modulus of elasticity and viscosity were obtained with the frequency of the samples obtained by substituting with puree a lower percentage of sugar and fat compared to the control sample. The sample obtained by substituting $40 \%$ of the amount of sugar and fat had the values of the viscosity module with the frequency closest to those of the control sample.

In the case of samples with a substitution of 20 and $50 \%$ of the amount of sugar and fat, the maximum gelatinization temperature had higher values than the control sample, and the samples with a substitution of 10 and $30 \%$ of the amount of sugar and fat had showed a lower maximum gelatinization temperature than the control sample. In contrast, the sample with a substitution of $30 \%$ of the amount of sugar and fat had a maximum gelatinization temperature as the control sample.

The behaviour of the dough at creep and recovery most similar to the control sample was in the case of the sample obtained by substituting $40 \%$ of the amount of sugar and fat, followed by the one with $50 \%$ substitution.

This is because the sugar and fat in apple puree have fulfilled the functions of sugar and fat added in the control sample.

Conclusions. A reduction of sugar between 10 and 50\% was achieved in 5 samples of pie dough. The use of apple puree as an ingredient in substituting a percentage of the amount of sugar and fat produced a dough with rheological properties approximately as the control sample depending on the percentage of sugar and fat substituted. 